International Journal of Social Sciences and Humanities
Available online at http://sciencescholar.us/journal/index.php/ijssh
Vol. 2 No. 3, December 2018, pages: $56 \sim 62$
e-ISSN: 2550-7001, p-ISSN: 2550-701X
https://doi.org/10.29332/ijssh.v2n3.193

\title{
Regulation of Protection and Fulfillment of Employee Rights of Go-Jek Drivers under Indonesian Employment Regulation
}

\author{
Kadek Januarsa Adi Sudharma a , Agus Putu Abiyasa ${ }^{\text {b }}$, Ni Ketut Elly Sutrisni ${ }^{\mathrm{c}}$ \\ Article history: Received 8 April 2018, Accepted: 30 August 2018, Published: 21 September 2018
}

\section{Correspondence Author ${ }^{\text {a }}$}

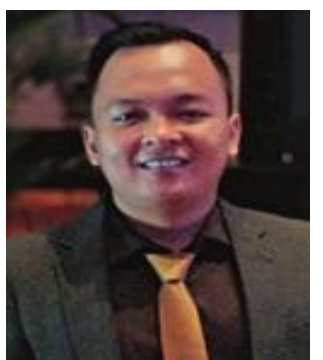

Keywords

Digital era;

Employment regulation;

Go-jek;

Law protection;

Right fulfillment;

\begin{abstract}
Go-Jek is the biggest and successful company which provides an online transportation solution for people in Indonesia through the mobile phone application by giving the impression of being the liaison between drivers and passengers. Go-Jek drivers are referred to as "partners" who can determine the amount of their income and their own working hours. However, in reality, the partnership relationship offered that aligns drivers with transport providers has exploitative relationships. The drivers are treated as informal workers without employment protection. Using technology, Go-Jek company has managed to set the drivers but still seem to have an equal relationship and give the freedom of employment as if there were no exploitation of the drivers. This rhetoric rests on the conventional concept of working relationships that the employer has the means of production and pays an hourly wage. The fact that the company only provides the application is always emphasized to create the impression that the driver is not a worker. So the system creates an imbalance of access and power that enables the company to keep drivers working and at the same time, the company eliminate the rights of drivers as workers and charge them and risk them.
\end{abstract}

e-ISSN: 2550-7001, p-ISSN: 2550-701X ๑ Copyright 2018. The Author. SS Journals Published by Universidad Técnica de Manabí. This is an open-access article under the CC BY-SA 4.0 license (https://creativecommons.org/licenses/by-sa/4.0/) All rights reserved.

\section{Contents}

Abstract 56

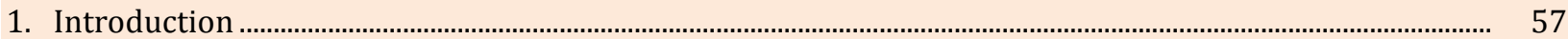

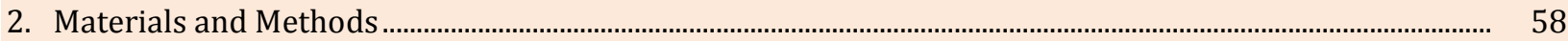

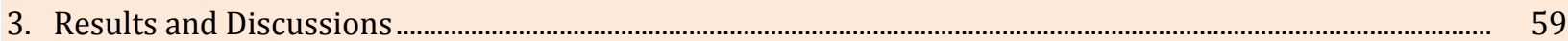

\footnotetext{
a Undiknas University, Bedugul Street No.39, Denpasar, Indonesia

b Undiknas University, Bedugul Street No.39, Denpasar, Indonesia

c Undiknas University, Bedugul Street No.39, Denpasar, Indonesia
} 
3.1 Analysis of work relationship between Go-jek driver and PT. Go-jek Indonesia

4. Conclusion...

Acknowledgements.

References.

\section{Introduction}

Started in the 1980s, the world has entered the digital era. The technology was not only about communication and entertainment. It has been invaded all aspect of human life significantly, included transportation. Now, transportation has grown considerably through the emergence of online transportation. It has changed people's lifestyles and how people live their life. This has influenced the way people order their transportation services, affect the cost of the transportation services, and provide more service options.

Starting with the emergence of Uber, the people of Indonesia began to recognize and interested in using the services of online transportation. In addition to its application-based system, it is also much cheaper than conventional taxi fares in general. Not only cars, but the motorcycle is also commonly used by the Indonesia people as their public transportation called Ojek. Its fares are lower than the cars.

In 2011, Ojek started to change as the development of technology and the demands of today's lifestyle. This change was marked by the establishment of PT. Go-Jek Indonesia or known as Go-Jek. Established by Nadiem Makarim, Go-Jek was then formed to help the Jakarta overcome its traffic congestion. Go-Jek offers a shuttle service with a modern system based on online orders. Now Go-Jek has grown very rapidly. Not only in Jakarta but has almost covered several major cities in Indonesia such as Surabaya, Jogyakarta, Bandung, and Denpasar-Bali. Go-Jek is now the fastest growing online transportation provider in Indonesia.

All the advantages and conveniences offered by Go-Jek have made Go-Jek increasingly popular and highly in demand. This popularity also raises the phenomenon of labor mobilization that encourages the creation of employment by attracting the interest of many people who already have a job or who have not yet to join as Go-Jek driver. In term of payment, Go-Jek applies a profit-sharing system where Go-Jek sets a 20:80 share. It is meant that from every order made, Go-Jek would get $20 \%$ and the driver would receive the rest of $80 \%$. In addition to getting paid from the consumer order, drivers also get bonuses from each transaction based on points collected. Therefore, become a Go-Jek driver could be a potential income source. Nevertheless, the income itself is determined by the discipline, motivation, and persistence of drivers in finding and getting consumers.

The partnership is a system that determined by Go-Jek to run their business and to work with all their drivers. As its system known quite different compared with other company, there is a need to do a deeper analysis. In its implementation, Go-Jek uses a partnership system based on the agreement of both parties. The agreement is made in a balanced position between each party. This implies that it is not possible for the drivers to obtain law protection based on the working relationship and the employment agreement pursuant to the Law of the Republic of Indonesia Number 13 the Year 2003 on Manpower.

In the civil law perspective, there is a difference between the employment agreement and the partnership agreement. However, the practice of Go-Jek with the driver of Go-Jek has a resemblance to the employment agreement. The employment agreement is said to be an agreement between the worker/laborer and the employer or employer which contains the terms of employment, rights, and obligations of the parties. In this case, it should be seen that not all elements in the partnership are the same as the work agreement. Some things may be equated as made by the parties, the obligations, and rights of the parties and the terms of employment (Martini, et al., 2018; Maba, \& Mantra, 2017). In addition to those problems, partnership practices are carried out with relationships that tend to be subordinated as in the employment agreement even though the juridical should be coordinative. This is one of the issues that need to be further explored to ensure that legal their rights.

Sudharma, K. J. A., Sutrisni, N. K. E., \& Abiyasa, A. P. (2018). Regulation of protection and fulfillment of employee rights of go-jek drivers under Indonesian employment regulation. International Journal of Social Sciences and 


\section{Materials and Methods}

This study uses normative legal research, by conducting Conceptual Approach, which uses legal doctrines approach that developed and relevant to the problem to review all regulations related to employment, then analyzed and elaborated descriptively qualitative.

\section{Results and Discussions}

\subsection{Analysis of work relationship between Go-Jek driver and PT. Go-Jek Indonesia}

Being a Go-Jek driver has become one of the popular jobs among the people in Indonesia. However, the clarity regarding the status of Go-Jek driver as a work can be reviewed by looking at some elements of the employment relationship in accordance with Law of the Republic of Indonesia Number 13 the Year 2003 on Manpower.

In Article 1 number 15 of Law no. 13 of 2003 on Manpower states that the employment relationship is a relationship between employers and workers/laborers based on employment agreements, which have elements of work, wages, and orders (van Voss \& Tjandra, 2012). (1) The element of work is fulfilled if the worker only performs the work that given by the company. (2) Wages, this element is met if workers receive compensation in the form of a certain amount in a certain period. Not by commission/percentage. (3) The command, this element is fulfilled if it comes from the company. Not on workers' initiative. On the other hand, the meaning of a worker itself is any person who works by receiving wages or other forms of remuneration. A worker must have a working relationship with a company in which the company is required to provide legal protection to its workforce (Asikin, 2004).

One type of agreement is the employment agreement which in the agreement will result in an employment relationship (Gunawan \& Jayantiari, 2015). Under the Manpower Act, the definition of an employment agreement is an agreement between a worker/laborer and an employer or employer who, under the terms of employment, rights, and obligations of the parties. The employment agreement generally only applies between the worker/laborer and the employer who organizes and the other person or other non-binding parties (Husni, 2003). The legal requirements of employment agreements between employers and workers are stipulated in Article 1320 of the Civil Code (Sjahputra, 2013). Workers declare their ability to work for employers by receiving wages and vice versa employers also declare their ability to hire workers by paying wages. Thus, the employment relationship between workers and employers is a form of employment agreement which basically contains the rights and obligations of each party (Dewi, et al., 2017).

According to the system that applied by Go-Jek, all driver does not receive wages/salary from the Go-Jek company. The driver earns their money depends on how many passengers they can serve. Orders to take passengers also do not come from the company, but from passengers. The order is also taken based on the willingness of the driver. In that condition, there is no element of the working relationship between the driver and the Go-Jek company. Therefore, the driver cannot be called as a worker in PT. Go-Jek Indonesia.

Reviewing the relationship built and established by PT. Go-Jek Indonesia with the driver is a partnership relationship between application providers and drivers. For that reason, the type of agreement used by Go-Jek is a partnership agreement, not a work agreement. A partnership agreement is a common form of a legal relationship between one party and the other on the basis of a partnership agreement. The general provisions of the partnership agreement are Article 1338 to Article 1320 of the Civil Code (Civil Code). Whereas, special provisions, may refer to the provisions of civil union in Article 1618 Civil Code up to Article 1641 of the Civil Code, namely the legal relationship between the parties between one partner and another by entering a "capital" as "inerrancy" (inbreng).

Both parties are bound by a regular agreement, which in this case back and subject to the rules of the Civil Code of the Covenant section. The lex specialis derogat, lex generalis principle does not apply in this case. The partnership relationship emphasizes the mutualism principle between the two parties. That is, this relationship is mutually beneficial and the position of the parties' equals. 
By using the basic type of agreement that is used is a partnership agreement then what happens is not a subordinate employee working relationship that has elements of work, wages, and orders, but equality between the parties in the partnership relationship. This is because in partnership there is no element of wages and orders. Thus the legal relationship between the employer of the application provider with the driver is the equivalent (partner) because there is no element of wages and orders. Thus, an employment relationship arises from a work agreement, not a partnership agreement. The Law of the Republic of Indonesia no. 13/2003 on Manpower cannot be used as a legal basis resulting in all workers' rights (in this case the drivers of Go-Jek) which are regulated and protected by the Manpower Act which is labor protection which can be in the form of guarantee of safety in work, protection in wage which can in the form of overtime pay, and protection in the welfare of the workforce such as the right to leave and severance pay if stops cannot be obtained by the driver.

\subsection{The Law Protection for Go-Jek Driver}

The definition of Legal Protection is to provide guidance to human rights harmed by others and the protection is given to the public so that they may enjoy all the rights granted by law or in other words the protection of the law is the various legal remedies which must be provided by law enforcement officers to provide a sense of security, both mind-and-body from interference and threats from any party.

Until now there is still a legal vacuum or arrangement about the providers of online transportation services and of course the drivers who participate in it. Moreover, Law Number 22 the Year 2009 of the Republic of Indonesia on Traffic and Road Transport, in Article 47 paragraph 3 only recognizes cars, buses, and other freight vehicles as part of public motor vehicles, which automatically motorcycles are not recognized as public transportation. It has occurred because the Government is more likely to pay attention to the public law than the civil law that is directly in synergy with the needs of the community. Whereas legal acts in the realm of the law of agreement is an act that is not less important to the public law because the realm of legal agreement especially the providers of online transportation services is one of the pillars of the nation's economy.

The law applied in the community will always have an interactive relationship with the values held by the community. This is in line with Soetandyo who stated:

\footnotetext{
"In an interactive relationship between the formal legal system sustained by the State authorities and the legal order of the people based on the foundations of community morality will create conversations about the extent to which law will be able to work effectively both in conservative roles as a means of control and in the role of more progressive as one of the facilitator factors that will facilitate social change." (Vago, 2015).
}

This is not understood by the regulators so as created a legal vacuum. It has happened in the arrangement of online transportation services which was born from advances in technology, information, and communication. This vacuum has an impact on the emergence of socio-economic negative effects.

The Government of Indonesia has sought to accommodate the emergence of this online transportation by issuing the Regulation of the Minister of Transportation of the Republic of Indonesia Number 108 the Year 2017 on the Implementation of Public Transport of Non-Motorized People Not in Trajectory, which is valid from April 1, 2018. Information technology-based applications companies can provide ordering services as they are currently running, however, applications companies are prohibited from acting as public transport providers. Other prohibited matters include providing access to applications to public transport companies that do not have a license to conduct Public Transport of Non-Road Drivers, providing application services to individuals, recruiting drivers, setting fares, and promoting fare below the border. Therefore, the Go-Jek drivers must complete the documents required by the Government of Indonesia. Unfortunately, the relationship between driver and the application provider company has not been set up so the drivers cannot work as a worker with their rights protected by the law, otherwise, the worker's rights as drivers contained in the Indonesian Manpower Act are still neglected.

Until now Government Regulation No. 108 of 2017 is not running maximally, and even will soon be revised again by the Government so that later will become legal umbrella to change of taxi company online, that Go-

Sudharma, K. J. A., Sutrisni, N. K. E., \& Abiyasa, A. P. (2018). Regulation of protection and fulfillment of employee rights of go-jek drivers under Indonesian employment regulation. International Journal of Social Sciences and 
Jek become public transportation company so that driver position which was only as partner transformed into a direct relationship with the company, or in other words is considered an employee.

The high competition between conventional and online transportation modes raises some unlawful events in the community. For example, many drivers who work on an online transport service provider gets bullied even severe injuries. There are also restrictions on accessing passengers in certain areas or known as red zones. The red zone is a zone where the driver of an online transport service provider cannot pick up passengers. This can certainly reduce the public interest to use these services and vice versa can also reduce the revenue of drivers of online transportation services.

The right of accessing passengers to an online transportation service provider will always be met if the government and the state do not change the traditional punishment (at least not eliminate the whole) that the community has practiced. Since the law has shifted its form, from the law that was born into a law that was formally ratified and deliberately rationalized, the Government is supposed to provide ideal efforts for the fulfillment of the right to access passengers on an online transportation service agreement. This is based on the principle of equality the law or equality before the law. According to this principle, the law views every human being the same and so must be treated equally (Darda Syahrizal, 2011).

\section{Conclusion}

The drivers of online transportation will not get legal protection from the Indonesian Manpower Law because they have no working relationship with the application provider company and the status as partners in accordance with the partnership agreement of PT. Gojek Indonesia. The Employment Act does not currently regulate the rights and protection of workers in new semi-informal working style relationships, such as those in the online transportation industry. It is expected that the Government of Indonesia will soon issue a regulation that accommodates workers 'rights from online drivers so that the fulfillment of workers' rights is fulfilled, one of them is by arranging an online taxi company, Go-Jek to become a public transportation company so that the driver's position, direct relationship with the company, or in other words considered as an employee thus creating a working relationship.

\section{Acknowledgements}

The authors would like to thank the editor of the International Journal of Social Science and Humanities for their support and advice. 


\section{References}

Asikin, Z. (2004). Agusfian Wahab dkk. Dasar-Dasar Hukum Perburuhan.

Darda Syahrizal, S. H. (2011). Kasus-kasus Hukum Perdata di Indonesia. Galangpress Publisher.

Dewi, I. G. A. A. O., \& Dewi, I. G. A. A. P. (2017). Corporate Social Responsibility, Green Banking, and Going Concern on Banking Company in Indonesia Stock Exchange. International Journal of Social Sciences and Humanities (IJSSH), 1(3), 118-134.

Gunawan, I. M. H., \& Jayantiari, I. G. A. M. R. Perlindungan hukum terhadap tenaga kerja berkaitan dengan adanya non competition clause dalam sebuah perjanjian kerja.

Husni, L. (2003). Pengantar Hukum Ketenagakerjaan Indonesia.

Maba, W., \& Mantra, I. B. N. (2017). An Analysis of Assessment Models Employed by The Indonesian Elementary School Teachers. International Journal of Social Sciences and Humanities (IJSSH), 1(1), 39-45.

Martini, L. K. B., Suardana, I. B. R., \& Astawa, I. N. D. (2018). Dimension Effect of Tangibles, Reliability, Responsiveness, Assurance, Empathy, Leadership towards Employee Satisfaction. International Research Journal of Management, IT and Social Sciences (IRJMIS), 5(2), 210-215.

Sjahputra, I. (2013). Teori dan kasus money laundering (pencucian uang). Harvarindo, Jakarta.

Vago, S. (2015). Law and society. Routledge.

van Voss, G. H., \& Tjandra, S. (Eds.). (2012). Bab-bab tentang hukum perburuhan Indonesia. Pustaka Larasan bekerja sama dengan Universitas Indonesia, Universitas Leiden, Universitas Groningen.

Sudharma, K. J. A., Sutrisni, N. K. E., \& Abiyasa, A. P. (2018). Regulation of protection and fulfillment of employee rights of go-jek drivers under Indonesian employment regulation. International Journal of Social Sciences and Humanities, 2(3), 56-62. https://doi.org/10.29332/ijssh.v2n3.193 


\section{Biography of Authors}

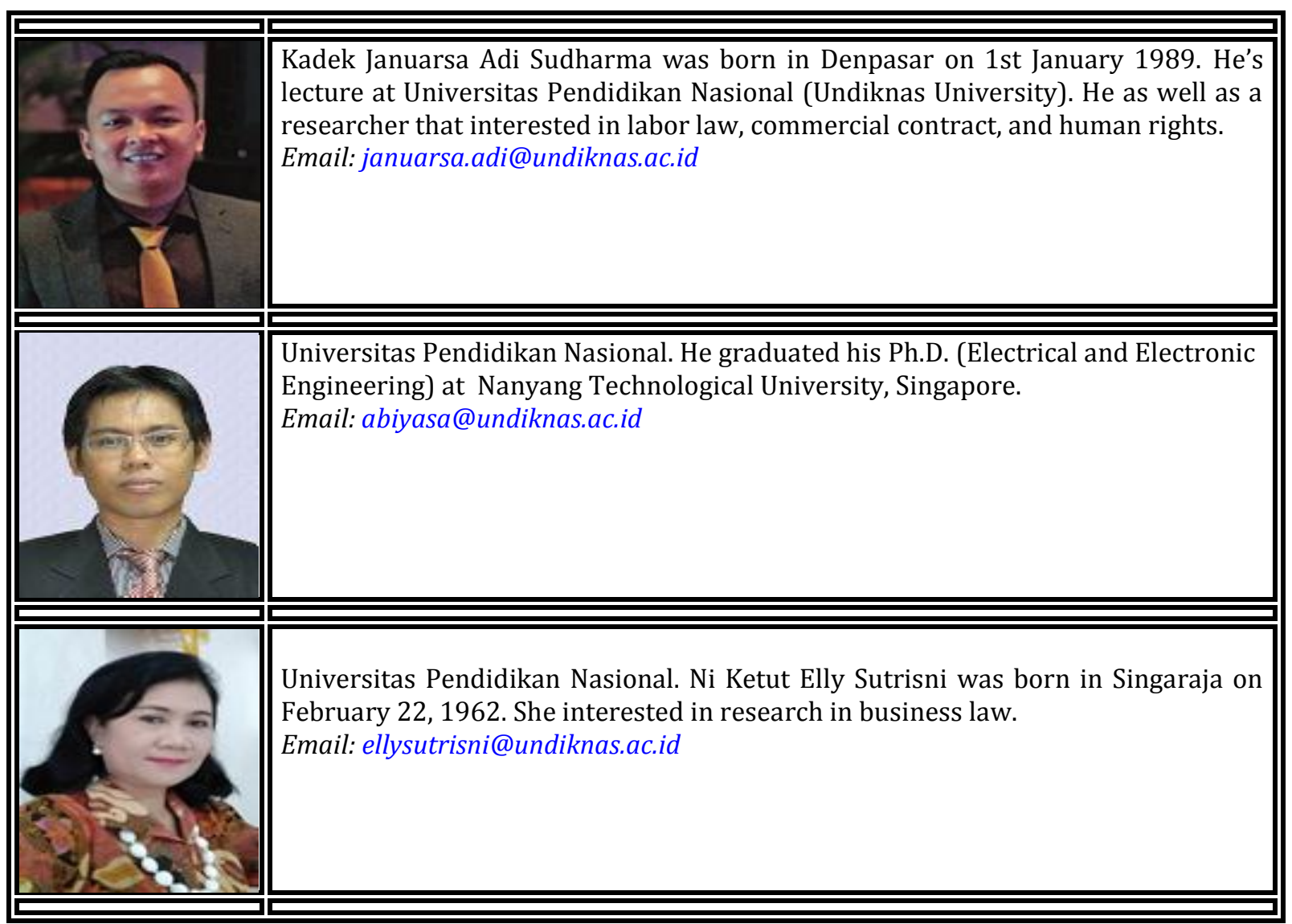

